\title{
PEMBERDAYAAN USAHA KECIL MENENGAH (UKM) DI DESA KOLAM KABUPATEN DELI SERDANG
}

\author{
Revita Yuni ${ }^{1)}$, Mesra $^{2)}$, Pebri Hastuti ${ }^{3)}$, Adek Cerah Kurnia Azis ${ }^{4)}$ \\ Universitas Negeri Medan ${ }^{1)}$ \\ Universitas Negeri Medan ${ }^{2}$ \\ Universitas Negeri Medan ${ }^{3)}$ \\ Universitas Negeri Medan ${ }^{4)}$
}

\begin{abstract}
ABSTRAK
Kegiatan Pengabdian kepada Masyarakat ini bertujuan untuk meningkatkan kualitas pembukuan keuangan, kualitas pengemasan dan merek dagang Usaha Kecil Menengah (UKM) di Desa Kolam. Permasalahan yang dihadapi oleh Mitra di sini yaitu; (1) pengelolaan keuangan bisa dikatakan belum maksimal dimana hanya menggunakan kertas bekas, penghitungannyapun hanya bersifat gali lobang tutup lobang (tidak ada perhitungan modal dan laba, tidak jarang modal dan laba digunakan untuk keperluan lain) dan (2) pengemasan keripik pisang menggunakan plastik gula kiloan sehingga kemasan sering bocor, sobek, dan tidak menarik serta belum memiliki merek dagang. Solusi yang ditawarkan di sini, Mitra diberikan pelatihan, pendidikan, pendampingan, sosialisai, dan penyerahan Teknologi Tepat Guna (TTG) mengenai permasalahan yang dihadapi oleh Mitra. Metode pelaksanaan program pengabdian akan dilakukan secara pendekatan yakninya perolehan informasi awal hingga proses kegiatan dilakukan dengan komunikasi secara langsung atau lewat alat komunikasi secara intensif dengan Mitra, sehingga pelaksanaan kegiatan dapat dilakukan secara terbimbing, dengan tujuan utama untuk meningkatkan kesejahteraan Mitra dalam mengelolah Usaha Kecil Menengah (UKM)nya, yaitu usaha keripik pisang.
\end{abstract}

Kata Kunci: UKM, Desa Kolam.

\begin{abstract}
The Community Service Activities aim to improve the quality of financial accounting, packaging quality and trademark of Small and Medium Enterprises (UKM) in Desa Kolam. The problems faced by Partners here are; (1) financial management can be said to be not optimal where only used paper is used, the calculation is only digging a hole in the hole (no calculation of capital and profit, not infrequently capital and profit used for other purposes) and (2) packaging banana chips using sugar plastic kilo, so the packaging is often leaky, torn and unattractive and does not have a trademark. The solutions offered here, Partners are given training, education, mentoring, socialization, and submission of Appropriate Technology (TTG) regarding the problems faced by Partners. The method of implementing the service program will be carried out in an approach that means the acquisition of initial information until the process of activities is carried out by direct communication or through an intensive communication tool with Partners, so that the implementation of activities can be guided, with the main objective of improving the welfare of Partners in managing Small and Medium Enterprises UKM), namely banana chips business.
\end{abstract}

Kata kunci: UKM, Desa Kolam.

\section{PENDAHULUAN}

Desa Kolam merupakan salah satu kampung tertua di kecamatan Percut Sei Tuan, yang didirikan pada tahun 1986 oleh Datuk Tengku Ulung. Letak Kampung Kolam berada di pinggir Sungai Percut, dengan wilayah meliputi Desa Bandar Setia sampai ke Desa Bandar
Klippa sekarang ini, masuk ke dalam wilayah Kecamatan Percut Sei Tuan.

Desa Kolam berbatasan langsung dengan Desa Saentis sebelah Utara, sebelah Selatan Desa Bandar Klippa, sebelah Barat Desa Bandar Setia, dan sebelah Timur Desa Sidodali Kecamatan Batang Kuis. Jumlah penduduk Desa Kolam yaitu 14.872 jiwa, yang terdiri dari 
7.839 jiwa laki-laki dan 7.033 jiwa perempuan, dengan jumlah Kepala Keluarga (KK) 2.403. (Profil Desa Kolam, 2016).

Berdasarkan jumlah penduduk dan KK yang ada di Desa Kolam di atas, sebagian besar bermata pencaharian bertani/ berkebun, buruh bangunan/tani, berdagang/wiraswasta, dan sebagian kecil sebagai Pegawai Negeri Sipil (PNS) dan pegawai/karyawan swasta. Beragamnya profesi penduduk yang ada di Desa Kolam merupakan keanekaragaman kekayaan keahlian yang dimiliki oleh masyarakat Desa ini, dimana kepala Desa Kolam berkeinginan besar untuk "Mewujudkan Masyarakat Desa Kolam yang Sejahtera". Salah satu usaha pemerintah Desa untuk mewujudkan masyarakat yang sejahtera, yaitu dengan memberikan kebebasan bagi masyarakatnya untuk berwirausaha, hal ini tidak hanya bagi kaum bapak-bapak saja, namun kaum Ibu-ibu juga bisa berwirausaha yang nantinya bisa membantu perekonomian yang lebih baik dalam sebuah keluarga.

Pemerintahan Desa Kolam sangat mendukung kegiatan-kegiatan rumahan yang bersifat positif misalnya dalam berwirausaha, dengan adanya Usaha Kecil Menengah (UKM) Rumahan, usaha rumahan ini bisa memanfaatkan hasil pertanian yang ada di Desa Kolam, para pemilik usaha tidak susah lagi mencari bahan baku untuk usaha tersebut. Hal ini terlihat dengan adanya UKM yang mengelolah hasil pertanian masyarakat Desa Kolam, yaitu memanfaatkan buah pisang. UKM ini mengolah pisang mentah menjadi keripik, usaha ini sudah berdiri selama 3 tahun terakhir.
UKM ini dalam setiap
harinya mampu memproduksi keripik pisang sebanyak 10 bungkus, yang dikemas dalam plastik polos bening (plastik khusus untuk gula kiloan) ukuran $2 \mathrm{~kg}, 1 \mathrm{~kg}, 1 / 2 \mathrm{~kg}$, dan $1 / 4 \mathrm{~kg}$, keripik dimasukan ke dalam plastik polos (plastik khusus untuk gula kiloan) kemudian diikat dengan karet gelang ada juga yang dilipat pada bagian atas selanjutnya dibakar menggunakan lilin pada sisi lipatan, untuk mengunci keripik tersebut tidak bocor dan masuk angin. Tidak jarang juga kemasan sering bocor ketika berada di warung atau ketika dalam pembungkusan produk, hal ini dikarenakan plastik yang digunakan adalah plastik untuk pengemasan gula kiloan, tidak plastik tebal yang khusus untuk makanan kering seperti keripik pisang.

Harga jual dari keripik pisang dibandrol dengan harga Rp. 2.000,(dua ribu rupiah) sampai dengan $\mathrm{Rp}$. 10.000,- (sepuluh ribu rupiah). Proses kegiatan mulai dari pengolahan bahan mentah, pembukuan keuangan, packing hasil produksi, sampai kepada penjualan/pemasaran dilakukan secara manual, yaitu pembukuan keuangan menggunakan kertas bekas, dengan sistem gali lobang tutup lobang (tidak ada perhitungan modal dan laba, tidak jarang modal dan laba digunakan untuk keperluan lain), pengemasan menggunakan plastik gula kiloan kemudian mengikat plastik dengan karet gelang atau membakar bagian atas plastik dengan lilin supaya tidak masuk angin, merek dagang/branding (nama merek, slogan, farian rasa, komposisi, gambar ilustrasi, alamat, nomor hand phone, dan hal lain yang berhubungan dengan branding) tidak ada. 
Ada beberapa kendala yang dihadapi oleh UKM di Desa Kolam, mulai dari pembukuan keuangan dan pengemasan. Hal ini yang membuat UKM di Desa Kolam tidak berkembang dengan baik, namun kendala yang ada tersebut dapat diatasi dengan mendatangkan ahli untuk membenahi kelemahankelemahan dari masing-masing bidang, mulai dari manajemen pembukuan keuangan dan desain kemasan. Dimana "sebuah keuletan, semangat, dan kreativitas mampu membangun usaha dari nol" (Sinamarata, 2012). Jadi sebuah usaha UKM yang ada di Desa Kolam besar kemngkinan untuk dapat berkembang lebih baik lagi, tentunya dengan keuletan, kreativitas yang tinggi, dan semangat kerja yang besar.

\section{METODE PELAKSANAAN}

\begin{tabular}{llr}
\multicolumn{2}{c}{ Motode } & pelaksanaan \\
dilakukan & sebagai & berikut: \\
melakukan & persiapan, & tahap
\end{tabular}
persiapan ini melakukan beberapa kegiatan yakninya: (a) sosialisasi program pengabdian kepada Mitra di Desa Kolam; (b) melaksanakan observasi dan mewawancarai Mitra serta melakukan diskusi untuk pemecahan masalah yang ada; (c) penentuan jadwal kegiatan; (d) saling berkomitmen antara pengabdi dengan Mitra; dan (e) mempersiapkan sarana dan prasarana untuk mendukung terlaksananya kegiatan Pengabdian kepada Masyarakat, (f) Focus Group Discussion (FDG) dengan Mitra, (g) pelatihan, pendidikan, dan pendampingan tentang pentingnya pembukuan keuangan dalam suatu usaha, (h) pelatihan, pendidikan, dan pendampingan bagaimana cara pengemasan produk keripik pisang, (i) pelatihan, pendidikan, pendampingan, dan sosialisasi pembuatan merek dagang.

\section{HASIL DAN PEMBAHASAN}

Kegiatan pengabdian kepada masyaraka ini menghasilkan luaran sebagai berikut: 1) buku panduan laporan keuangan, 2) kemasan plastik stand up pouch klip zipper, 3) soft copy merek dagang, 4) stiker merek dagang, 5) alat pemotong (karter dan gunting), 6) mesin cetak (printer), dan 7) alat perekat (sealer).

Berikut produk yang dihasilkan selama kegiatan pengabdian kepada masyarakat dilakukan:

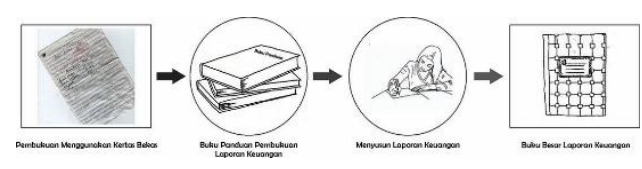

Gambar 1. Buku Panduan Laporan Keuangan yang Sudah Tersusun Rapi.

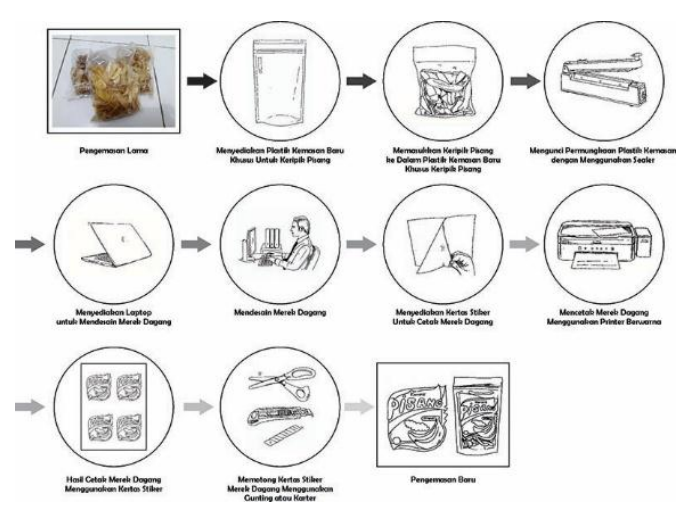

Gambar 2. Desain Kemasan dan Merek Dagang . 
Beberapa kepakaran yang dibutuhkan dalam pencapaian hasil kegiatan yang maksimal sebagai berikut: 1) Ahli Pembukuan Keuangan Rasional: dalam kegiatan pelatihan, pendidikan, dan pendampingan yang dilakukan pada UKM di Desa Kolam tentang penyusunan laporan keuangan, maka dengan itu perlu didatangkan pakar dalam bidang ekonomi, terkhusus perekonomian usaha kecil menengah dan 2) Ahli Desain Kemasan dan Desain Produk rasional: dalam upaya pengemasan, pembuatan merek dagang pada UKM di Desa Kolam perlu adanya pelatihan, pendidikan, pendampingan, dan sosialisasi yang langsung mendatangkan pakar Seni Rupa dan Desain.

\section{KESIMPULAN}

Kegiatan Pengabdian kepada Masyarakat ini bertujuan untuk meningkatkan kualitas pembukuan keuangan, kualitas pengemasan dan merek dagang, dan kualitas pemasaran Usaha Kecil Menengah (UKM) di Desa Kolam. Permasalahan yang dihadapi oleh Mitra di sini yaitu; (1) pengelolaan keuangan bisa dikatakan belum maksimal dimana hanya menggunakan kertas bekas, penghitungannyapun hanya bersifat gali lobang tutup lobang (tidak ada perhitungan modal dan laba, tidak jarang modal dan laba digunakan untuk keperluan lain), pengemasan keripik pisang menggunakan plastik gula kiloan sehingga kemasan sering bocor, sobek, dan tidak menarik serta belum memiliki merek dagang, dan (3) penjualan bersifat tradisonal hanya dijual di warung depan rumah saja dan dari warung ke warung disekitar Desa Kolam.

Solusi yang ditawarkan di sini, Mitra diberikan pelatihan, pendidikan, pendampingan, sosialisai, dan penyerahan Teknologi Tepat Guna (TTG) mengenai permasalahan yang dihadapi oleh Mitra. Target khusus yang telah dicapai dalam pengabdian ini yaitu: (1) panduan pembukuan keuangan dan pembukuan keuangan menggunakan buku besar yang dirancang untuk menghitung keuangan usaha, (2) pengemasan keripik pisang sudah menggunakan plastik tebal yang didesain khusus untuk makanan kering sehingga tidak mudah bocor, tidak mudah sobek, dan tentunya sangat menarik, dan sudah memiliki merek dagang, (3) penjualan sudah berbasis online dan juga sudah bisa dipasarkan di luar Desa Kolam. Luaran yang dihasilkan dalam kegiatan Pengabdian kepada Masyarakat ini sebagai berikut: (1) buku panduan pembukuan keuangan, (2) buku besar pembukuan keuangan, (3) plastik kemasan yang sudah terstandar yang khusus untuk makanan kering seperti keripik pisang, (4) merek dagang (soft copy) dan yang dicetak di atas kertas stiker, (5) alat perekat kemasan plastik (sealer), (6) alat pemotong kertas stiker (pisau karter dan gunting), (7) alat untuk pemasaran online (leptop), (8) modem data untuk pemasaran online, dan (9) alat cetak stiker (printer). Metode pelaksanaan program pengabdian dilakukan secara berjenjang, berkesinambungan, dan komprehensif yang dilaksanakan melalui metode pendekatan. Pendekatan di sini dimaksudkan adalah perolehan informasi awal hingga proses kegiatan dilakukan 
dengan komunikasi secara langsung atau lewat alat komunikasi secara intensif dengan Mitra, sehingga pelaksanaan kegiatan dapat dilakukan secara terbimbing, dengan tujuan utama untuk meningkatkan kesejahteraan Mitra dalam mengelolah Usaha Kecil Menengah (UKM)nya, yaitu usaha keripik pisang.

\section{REFERENSI}

Pemerintah Desa Kolam. (2016).

Profil Desa Kolam. Deli Serdang: Pemerintah Desa Kolam.

Sinamarata, Herry. (2012). Inspirasi Sukses 30 Pelaku Bisnis UKM. Jakarta: Kompas Gramedia. 